\title{
Article
}

\section{The Methodology for Designing Residential Buildings with a Positive Energy Balance-General Approach}

\author{
Bartosz Radomski * and Tomasz Mróz (D) \\ Faculty of Environmental Engineering and Energy Poznan, University of Technology, Berdychowo 4, \\ 60-965 Poznań, Poland; tomasz.mroz@put.poznan.pl \\ * Correspondence: bartosz.radomski@put.poznan.pl
}

check for updates

Citation: Radomski, B.; Mróz, T. The Methodology for Designing Residential Buildings with a Positive Energy Balance-General Approach. Energies 2021, 14, 4715. https:// doi.org/10.3390/en14154715

Academic Editor: Rajendra Singh Adhikari

Received: 20 June 2021

Accepted: 28 July 2021

Published: 3 August 2021

Publisher's Note: MDPI stays neutral with regard to jurisdictional claims in published maps and institutional affiliations.

Copyright: (c) 2021 by the authors. Licensee MDPI, Basel, Switzerland. This article is an open access article distributed under the terms and conditions of the Creative Commons Attribution (CC BY) license (https:/ / creativecommons.org/licenses/by/ $4.0 /)$.

\begin{abstract}
This a presents an original methodology for designing residential buildings with a positive energy balance. This process is an extremely complex undertaking. So far, no methodology with an open set of decision criteria has been developed that would include the modeling of the decisionmaker's preferences using statistical surveys of a group of decisionmakers for this purpose. There is also no methodology relating to the interdependence of decision criteria. The present paper presents an original methodology consisting of five stages. The prepared algorithm indicates the need for changes in the classic design of residential buildings, taking into account the decision criteria that show interdependence. The proposed methodology consists in combining three methods of multi-criteria decision support: the DEMATEL method, used to determine the relations between decision criteria; the AHP / ANP method, used to build a model of the decisionmaker's preferences, and the TOPSIS method, used to create a ranking of permissible and acceptable variants of solutions. The tool, i.e., the DEMATEL method, fulfills the expected function and enables the identification of the relations between the criteria and sub-criteria of evaluation. The AHP/ANP method fulfills the expected function and enables the ranking of evaluation criteria and sub-criteria.
\end{abstract}

Keywords: plus energy buildings; planning methodology; multicriteria analysis

\section{Introduction}

As a result of the depletion of natural resources, which are carriers of conventional energy, the increase in the wealth of society and the ease of obtaining energy, as well as the trend of limiting the consumption of primary energy in all its forms, which continued for some time, buildings are created in accordance with the idea of sustainable development. The built environment is responsible for around $30-40 \%$ of the world's total primary energy consumption. Therefore, it has a high reduction potential that can be used to improve the energy performance of individual structures [1-7].

Establishing a policy implementing the sustainable development strategy in the world was the entry point for the introduction of normative provisions in the housing industry that clearly limit the demand for energy in this sector. The effects were achieved mainly by tightening the requirements for thermal insulation of building envelopes and defining limitations concerning the value of the annual primary energy (PE) demand index. Directive 2010/31/EU of the European Parliament and of the Council of 19 May 2010 [8] introduced a concept of a nearly zero-energy building (nZEB). Thus, the minimum standard of newly erected buildings was defined and it is fully applicable from 1 January 2021 for all newly constructed buildings.

A standard ahead of the European requirements in terms of energy efficiency is the idea of a passive house, in line with the standards of the Passive House Institute (PHI), which combines high living comfort with very low energy consumption. Passive house construction is characterized by excellent energy efficiency, optimal thermal comfort and a high degree of user satisfaction with the surrounding conditions, but also protection against 
potential damage caused by excessive condensation of water vapor [9-16]. A residential building designed in accordance with the idea of a passive house should function as a starting point and meet the fundamental requirements of designing buildings with a positive energy balance. Nearly zero-energy buildings (nZEBs) and basic passive buildings are already, in the design process, treated as intermediate stages. A building or a group of buildings with a positive energy balance is an energy-independent structure, it does not require the use of conventional energy sources for heating, cooling and electricity [15-17].

The process of designing residential buildings with a positive energy balance is an extremely complex undertaking. It is accompanied by informational, technical, energy, exergy, economic, social and environmental factors that require continuous decision-making in order to achieve the intended goal, which can after all be accomplished in many different ways. The methods are in close connection to solutions (variants), and the variants are accompanied by the factors mentioned above. These are measurable characteristics, but they are also sometimes difficult to measure, most often they interact with each other. An indication of the most favorable variant (a compromise solution) is accompanied by a specific decision situation resulting from the characteristics of the problem and the evaluation criteria. The choice of the best variant is supported by knowledge, experience and intuition, but with the increasing complexity and scale of problems, it becomes necessary to support decisions with methods of operational research, i.e., the so-called multi-criteria methods of supporting the decision-making process. Using them makes it possible to determine a set of permissible solutions, and after indicating the decision-making criteria and determining the preferences of the decisionmaker, it enables the choice of a compromise solution.

Entities responsible for the design and operation of sustainable buildings need clear and reliable building evaluation tools [18-21]. Currently, there are many methods for measuring and evaluating the environmental performance of a building, often referred to as building rating systems (BRSs). The two most common ones are the English BREEAM method and the American LEED method [22]. Unfortunately, there is no methodology for designing a residential building with a positive energy balance, which makes it difficult to start the construction process. So far, no methodology with an open set of decision criteria has been developed that would include the modeling of the decisionmaker's preferences using statistical surveys of a group of decisionmakers for this purpose. There is also a lack of methodology relating to the interdependence of decision criteria [22-41].

It is necessary to develop a methodology for designing residential buildings with a positive energy balance, consistent with the idea of sustainable development, allowing for a reduction in global consumption of non-renewable primary energy in the household sector, based on an open set of criteria and parameters, in accordance with the specific preferences of the decisionmaker, and taking into account the relations between decision criteria. The choice of a compromise solution becomes a decision problem that requires the use of one (or many) of the multi-criteria methods supporting decision-making.

The main goal of this paper is to present an innovative methodology for designing residential buildings with a positive energy balance in accordance with the principles of sustainable development. A large number of available methods makes it difficult to make the best choice. The final decision was influenced by many factors, including the nature of the issue under consideration, the potential of the method, the construction or use of an existing tool, its perception, flexibility, speed and ease of use. Undoubtedly, the choice of method is itself a decision problem. However, there are universal solutions, the usefulness of which was tested on many practical examples, especially those related to construction, to obtain the desired and satisfactory results of the analyses [32-39].

The present paper discusses the AHP/ANP-DEMATEL-TOPSIS approach. The developed methodology consists of five stages. The first is the construction of an input database for a specific project, the second is the identification of permissible and acceptable solutions. The third stage is the creation of a set of decision criteria and the identification of the relation between them, which is determined by surveying a group of experts using the Delphi method. To identify the relation between decision criteria, the DEMATEL method 
and an original expert team survey questionnaire is used. The aim is to determine the weights of the relations between criteria $\left(\mathrm{v}_{\mathrm{i}}\right)$. Pairwise comparisons are made with respect to all combinations of interrelations between elements and their groups. The fourth stage consists in determining the preferences of the decisionmaker with the use of a target group survey utilizing social research. In order to compare pairs of decision criteria based on the set goal, i.e., the selection of a residential building with a positive energy balance, the AHP/ANP method is used together with an original questionnaire surveying the target group: decisionmakers clearly interested in the construction of the buildings in question. The aim is to determine the weights of the criteria preferences $\left(w_{c}\right)$. An algorithm completes the fifth stage, in which the values of the variables are calculated and normalized, and a ranking of permissible and acceptable variants of solutions is created, concluded with the choice of a compromise solution. The TOPSIS method is used to create the final ranking of permissible and acceptable solutions. The prepared algorithm indicates the need for changes in the classic design of residential buildings, taking into account the decision criteria that show interdependence.

\section{Methodology}

An original methodology (algorithm) for designing residential buildings with a positive energy balance was created. The general algorithm consists of five main stages, as presented in Figure 1.

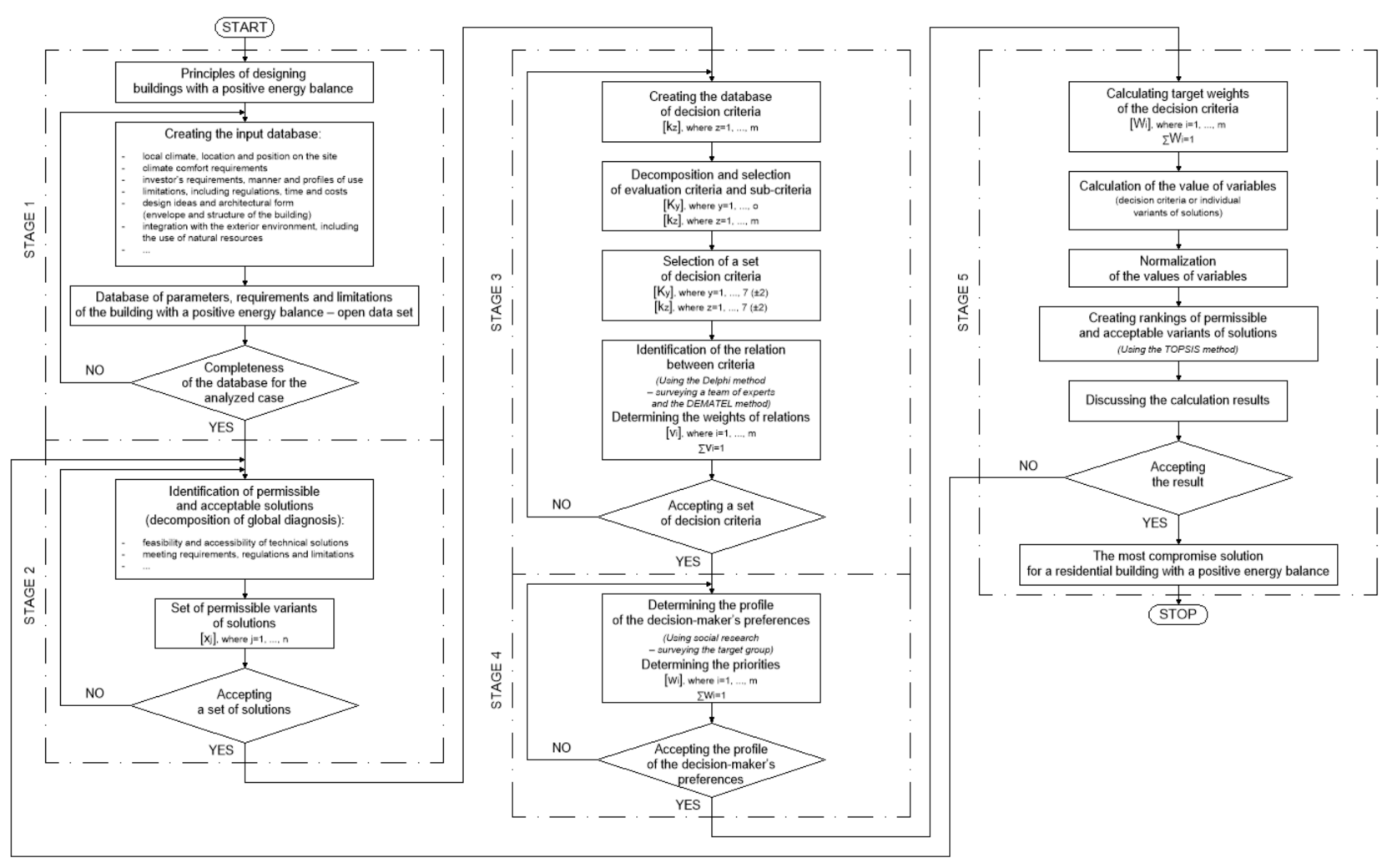

Figure 1. Methodology for designing a residential building with a positive energy balance.

\subsection{STAGE 1-Creating the Input Database for a Specific Project}

The creation of the input database is carried out in accordance with the basic principles of designing residential buildings with a positive energy balance. It is created for a specific analyzed case at the initial stage of the designing process. It takes into account, for example, local climate (meteorological data), location, orientation and position on the site of the planned building, detailed climatic comfort requirements, the investor's instructions and 
guidelines, the expected type and profiles of the use of the building, global and local restrictions, including regulations, access to utilities, the maximum time and costs of the project execution, design ideas and the architectural form acceptable to the decisionmaker, but also the impact of the building on the external environment and the use of natural resources, including the role of passive energy systems and the introduction of renewable energy. The input database is an open set. It can contain a different number and quality of variables, depending on the complexity of the building and the time to make key decisions. After creating a complete input database for the analyzed case, proceed to the second stage. Otherwise, the database must be completed with further data.

\subsection{STAGE 2-Identification of Permissible and Acceptable Solutions for a Residential Building with a Positive Energy Balance}

After creating the input database for a specific investment, proceed to the second stage, i.e., identification of technical solutions the decisionmaker allows and accepts, which are realistic and available for a specific case, meeting the previously imposed requirements, guidelines and restrictions. Often the set of allowable variants is finite and discrete. This stage uses a decomposition of a global diagnosis, creating an observation matrix that features the above elements. In this way, a set of possible variants of solutions is created, and after its approval, proceed to the third stage.

\subsection{STAGE 3-Selection of a Set of Decision Criteria and Identification of the Relations between the Criteria}

During this stage, a set of decision criteria and sub-criteria is selected. In the proposed methodology, they were decomposed and selected on the basis of an extensive literature review, and summarized in Table S1 in Supplementary Materials. Next, the DEMATEL method is used to identify the relations between all evaluation criteria and sub-criteria, and to find out the weights of these relations, which are determined using the Delphi method, i.e., an expert group. The evaluations made by selected experts is collected and a statistical analysis is carried out. The study is described in detail in Section 3.1. The determined relation weights are used in the last stage of the proposed methodology. If the set of decision criteria is accepted, proceed to stage four of the methodology, otherwise the set of decision criteria should be adjusted.

\subsection{STAGE 4-Determination of the Profile of the Decisionmaker's Preferences}

After selecting an acceptable set of decision criteria, it is necessary to define the profile of the decisionmaker's preferences, which is prepared using a social research method, i.e., target group survey. A statistical survey of a representative population should be conducted to obtain the answers, and a statistical analysis should be performed. The study is described in detail in Section 3.2. After analyzing the collected data, a target profile of the decisionmaker's preferences is created, which includes the assignment of direct weights to previously selected decision criteria and sub-criteria. If the created profile is accepted, proceed to the fifth stage of the methodology, otherwise it is necessary to re-survey, expand or narrow the target group.

\subsection{STAGE 5-Choosing a Compromise Solution}

The last stage of the methodology is calculating the values of variables and choosing a compromise solution. First, target weights of the decision criteria should be determined. They are calculated on the basis of previously obtained relation weights and the decisionmakers' priorities using Equation (1).

$$
W_{i}=\frac{v_{i} \cdot w_{i}}{\sum_{j=1}^{n} v_{i} \cdot w_{i}}
$$

where:

- $\quad W_{i}$ is the target normalized weight of each evaluation sub-criterion, where $\sum W_{i}=1$; 
- $\quad v_{i}$ is the normalized weight of a relation, previously determined using the DEMATEL method, where $\sum v_{i}=1$;

- $w_{i}$ is the normalized weight of a preference, previously determined using the AHP/ ANP method, where $\sum w_{i}=1$.

Next, the values of the variables characterizing individual variants of solutions should be calculated, and the minimum and maximum permissible values for individual indicators should be compiled. The calculated values of the variables (indicators) are normalized according to Equations (2) and (3).

For stimulants:

$$
n_{i, j}=\frac{Q_{i, j}}{Q_{M A X, j}}
$$

For destimulants:

$$
n_{i, j}=\frac{Q_{M I N, j}}{Q_{i, j}}
$$

where:

- $\quad Q_{i, j}$ is the calculated value of the indicator for the $i$-th variant and the $j$-th criterion;

- $Q_{M A X, j}$ is the maximum permissible value of the indicator for the $j$-th criterion;

- $Q_{M I N, j}$ is the minimum permissible value of the indicator for the $j$-th criterion.

Once the indicators are normalized, all evaluation sub-criteria are stimulants. Next, the obtained normalized values are multiplied by the target weights of the evaluation criteria. In order to create a ranking of permissible and acceptable variants of solutions, the TOPSIS method was chosen, which was also used to identify the theoretical positive-ideal and negative-ideal solution (variant). It allows a determination of the distance between the vectors of values describing a given variant and the vectors corresponding to the positive-ideal variant and the negative-ideal variant. The most advantageous variant is the one whose value vector has both the shortest distance from the positive-ideal variant vector and the longest distance from the negative-ideal variant vector. Next, the calculation results are discussed, the results of the analysis are accepted and a compromise solution for a residential building with a positive energy balance is chosen. If the result of the analysis is not accepted, it is necessary to return to stage two, extend the set of permissible variants of solutions and/or change the set of decision criteria, and/or define a new profile of the decisionmaker's preferences.

\section{Conducted Research}

The choice of a residential building with a positive energy balance is a decision issue. The decisionmaker is the one looking for a compromise (ideal) solution among the permissible solutions (variants). This process results in achieving the goal (choosing a compromise solution) and identifying the order of preference in a specific set of variants. When creating a ranking of permissible solutions, the selected assessment criteria (set of identified characteristics), the weight of the relations and the decisionmaker's preferences are taken into account. Then the selection of the best variant comes down to the selection of the variant with the highest preference.

Preferences can be formulated in two ways. Firstly, by taking into account an appropriate numerical scale (distinguishing between incomparability), and secondly, by knowing certain measures of the characteristics of comparable objects (solutions). Determining the dependence (relation) of individual assessment sub-criteria within all sub-criteria is independent of the decisionmaker's preferences, and are the responsibility of a team of experts in line with the research carried out using the Delphi method (for details see Section 3.1). Determining the preference dependent on the decisionmaker consists in defining the weights of individual evaluation sub-criteria in a given group of the main decision criteria and the main criteria alone. For this purpose, a target group was surveyed with the use of social research, the results of the research are presented in Section 3.2. 
For both cases, i.e., in order to determine the relations between individual evaluation sub-criteria within all sub-criteria, and to determine the weights of individual evaluation sub-criteria in a given group of decision criteria, two different questionnaires were prepared. First, for both trial surveys, independent pilot studies were conducted to test the questionnaires (group of five respondents). The criteria for the validity of the test were verified, including objectivity, standardization, reliability, accuracy, norms, appropriate adaptation and general features of the questionnaires, as well as their understandability, transparency, length, and the respondents' reactions. The pilot study resulted in a simplification of the structure of the questionnaire by changing individual questions aimed at pairwise comparison into compact tables. The vast majority of the questions asked are used to confirm the research assumptions: achieving the goals: direct; determining the numerical values of the evaluations of individual pairwise comparisons made, and indirect; assigning oneself to a specific group of respondents, assessing one's own knowledge and expertise in relation to the selected type of construction and to given groups of evaluation criteria (it allows potential weighting of the respondent's answers). Moreover, a number of personal questions were added to define the respondent's profile; education, age, and place of residence. This study does not take into account the answers to such detailed questions, they are for informational purposes only. The data can be used in the future. Both questionnaires are summarized by a question about the time spent on completing the questionnaire.

It is crucial that the created questionnaires are not only checked in terms of methodology, but also characterized by high reliability and accuracy of the evaluation made by the respondents. For this purpose, one of the features of the ANP method was used, i.e., the possibility to assess the quality of the respondents making comparisons (in the first case, a team of experts, and in the second, a specific group of decisionmakers). Based on the geometric consistency index (GCI) determined within individual matrices for a group of evaluations made by respondents participating in the survey, it is calculated to what extent the transitivity of the evaluation is preserved; that is, it indicates whether relations (impact/preference) are logically evaluated for each group of components, e.g., for the three components $\mathrm{a}, \mathrm{b}, \mathrm{c}$; if $a$ is preferred over $b$ and $b$ is preferred over $c$, then $a$ is also preferred over $c$. In the case of inconsistency of evaluation for the collected group of respondents (experts or decisionmakers), i.e., for a situation where GCI > GCI $\mathrm{Ferm}_{\text {., }}$ not meeting the conditions results in the necessity of revising the values assigned by all $\mathrm{K}$ respondents.

\subsection{The Delphi Method, the Expert Team Study, Determining the Relations between Criteria}

The Delphi method, the expert team study, aims to determine the relations between individual components of the decision network. According to the ANP/DEMATEL method, pairwise comparisons are made with regard to all combinations of interrelations between elements $[40,41]$. The ANP method uses a nine-point scale of comparisons, the so-called Saaty's scale, which was the scale used in the study.

The DEMATEL method was used to determine the relations between individual evaluation criteria. The evaluating entity, in accordance with the Delphi method, is a group of experts, which was surveyed using an original expert questionnaire.

Evaluation of the intensity of the impact between individual decision criteria and sub-criteria requires the participation of experts. Their opinions are usually different, and their positions are built on the basis of various priorities, systems of values, competences, knowledge resources or education and expertise. For this purpose, it is necessary in the first place to create an expert questionnaire, select a target group (team of experts), conduct a survey and finally conduct a statistical analysis.

According to the DEMATEL method and the Analytic Network Process (ANP), all criteria and sub-criteria of evaluation had to be compared, both within individual groups of decision criteria and for each evaluation sub-criterion. A discrete and non-negative evaluation was used, i.e., a nine-point scale that symbolizes the intensity of the impact 
of an evaluation criterion in pairwise comparison on the other criterion, including point zero corresponding to the lack of direct impact. The respondent, using the relation degree (relation/impact) used to evaluate pairwise comparisons and interpreted in the manner presented in the questionnaire, was asked to assign the value of the relation for each pair (determining the intensity of impact), from absolute impact $(-9 /+9)$ to no impact $(0)$, which in the respondent's opinion, contributes to the achievement of the goal, i.e., the selection of the most favorable solution for residential buildings with a positive energy balance. All questions regarding the determination of the intensity of impact were closed-ended, in each of them the respondent marked a numerical value on the Saaty's scale axis. The pairwise comparison method was used; it is the easiest way for the respondents to provide the correct answer due to its intuitiveness. In all cases, the decision sub-criterion on the left side of the scale was compared to all the other decision sub-criteria on the right side. The pairs were grouped according to the order of decision criteria and sub-criteria in a tabular manner. Hence, the questionnaire became legible and transparent and the use of such a solution facilitated the process of filling it in, and a situation in which the respondents were unable to provide answers was excluded. Another advantage of the adopted survey structure is the easier statistical analysis of the data.

An important element of the research carried out using the Delphi method is the correct selection of the sample and quality of respondents, i.e., people who have the appropriate knowledge and expertise in the analyzed subject. The prepared expert questionnaire was addressed to experts in the field of architecture and urban planning, construction, environmental engineering or energy. The selection of the group of respondents for the study was intended and strictly defined, it consisted of people employed in scientific units, research units and operating in business who should be considered experts due to their interests, knowledge and expertise.

The expert questionnaires were distributed in three categories:

1. Source_a; experts from the Poznań University of Technology, 16 respondents;

2. Wersja_1; experts from other scientific and research units, 57 respondents;

3. Ver_1; specialists from the industry, 15 respondents.

The paper-based expert questionnaire was sent to a total of 73 experts employed in scientific units and research units, as well as to 15 specialists from the industry. Completed questionnaires were received from 8 experts from the Poznań University of Technology, 12 experts from other universities and research units, and 11 industry specialists. In total, out of 88 sent questionnaires, 31 were completed, which is $35.2 \%$. Table S2 shows the distribution of the frequency of the evaluation marks provided by all experts.

For the statistical evaluation of the obtained data and the results of the survey, the geometric mean is used, which is one of the measures of the average (position measures), which indicate a value typical for the surveyed population. It allows an evaluation of the average measurable characteristic in a statistical population and was determined according to Equation (4):

$$
\bar{x}=\sqrt[n]{x_{1} f_{1} \cdot x_{2} f_{2} \cdot \ldots \cdot x_{k} f_{k}}=\sqrt[n]{\prod_{i=1}^{k} x_{i} f_{i}}
$$

where:

- $\quad x_{i}$, value of a variable in a series;

- $n$, number of variables in a series;

- $\quad k$, number of variables with the same value in a series.

In Table S2, the last column shows calculations of the geometric consistency index (GCI). The collected evaluations by the surveyed target group show high reliability and accuracy of the evaluations made by the respondents. There are no grounds for revising the value of the evaluations made by all $\mathrm{K}$ respondents.

In the case of the proposed methodology for designing buildings with a positive energy balance, the individual evaluation criteria and sub-criteria are most often interdependent. It 
is essential to determine the relation between individual evaluation criteria and sub-criteria. For this purpose, the potential of the DEMATEL method was used.

In order to determine the intensity of the impact of individual decision criteria and subcriteria on the remaining ones, it was decided to use the geometric mean of the evaluations obtained as a result of the Delphi study. It was concluded that if for a given pair of decision criteria the majority of experts (at least 16 out of 31 respondents) indicate the value of the relation to be 0 , then it is assumed that these criteria show no impact to each other (i.e., there is lack of impact).

The next step was to create a direct-relation matrix, a normalized direct-relation matrix and a total-relation matrix. All matrices were created for the main criteria and the subcriteria of the evaluation, see Table S3. Table 1 shows the role and importance of individual components in terms of the total impact. The $s+(D+R)$ indicator defines the position, prominence and gross influence, while the $s-(D-R)$ indicator defines the relation and/or net influence. The higher the value of the s+ indicator for a given criterion/sub-criterion, the higher the level of interrelations with other criteria/sub-criteria. Both indicators are stimulants: the first; with increasing preference (the higher the indicator value, the greater the importance of the parameter), the second; determining the cause $(s->0)$ or effect $(s-<0)$ character. Table 1 shows the causal factors $(s->0)$ in bold, while the effect criteria $(s-<0)$ are in italics. By creating a composition of the main criteria and sub-criteria of evaluation that describe buildings with a positive energy balance, a hierarchy and correlation between individual elements can be shown on the cause-and-effect diagram.

Table 1. The role and importance of individual main criteria and sub-criteria of evaluation.

\begin{tabular}{|c|c|c|c|c|c|}
\hline & $\mathbf{D}+\mathbf{R}$ & $\mathbf{D}-\mathbf{R}$ & & $\mathbf{D}+\mathbf{R}$ & $\mathbf{D}-\mathbf{R}$ \\
\hline & $\mathrm{s}+$ & $\mathrm{s}-$ & & $\mathrm{s}+$ & $\mathrm{s}-$ \\
\hline$c_{T}$ & 3.28 & -1.01 & $\mathbf{c}_{\mathrm{T}} \mathrm{A} / \mathrm{V}, \mathbf{i}$ & 0.99 & 0.99 \\
\hline$c_{\text {EN }}$ & 3.1 & 0.73 & $\mathrm{c}_{\mathrm{T}} \mathrm{T}, \mathrm{BLD}, \mathrm{i}$ & 0.28 & 0.13 \\
\hline$c_{E X}$ & 2.69 & 1.42 & $\mathrm{C}_{\mathrm{T}} \mathrm{D}, \mathrm{IMP}, \mathrm{i}$ & 0.3 & 0.06 \\
\hline$c_{E C}$ & 3.08 & 0.4 & $\mathrm{c}_{\mathrm{T}}$ T,LIFE,i & 0.21 & 0.07 \\
\hline $\mathrm{c}_{\mathrm{S}}$ & 2.95 & -0.59 & $\mathrm{c}_{\mathrm{T}} \mathrm{T,RES,i}$ & 0.21 & -0.08 \\
\hline \multirow[t]{5}{*}{ CENV } & 3.12 & -0.95 & $\mathrm{C}_{\text {EN PE,TOTAL,i }}$ & 1.07 & -0.95 \\
\hline & & & CEN UE,TOTAL,i & 0.69 & 0.36 \\
\hline & & & CEN FE,TOTAL,i & 0.75 & -0.003 \\
\hline & & & CEN UE,RES,i & 0.49 & 0.27 \\
\hline & & & $c_{\text {EN FE,RES,i }}$ & 0.47 & 0.06 \\
\hline $\mathrm{c}_{\mathrm{EX}} \mathrm{B}, \mathrm{L}, \mathrm{i}$ & 0.44 & 0.23 & CS TC,i & 0.2 & 0.01 \\
\hline$c_{\text {EX B,GEN,RES, i }}$ & 0.6 & 0.39 & $\mathrm{C}_{\mathrm{S}} \mathrm{AQ}, \mathrm{i}$ & 0.13 & 0.08 \\
\hline CEX B,P, i* & 0.4 & -0.16 & CS AC,i & 0.15 & -0.04 \\
\hline CEX UTIL,RES, i & 0.61 & 0.38 & CS VC,i & 0.18 & -0.06 \\
\hline $\mathrm{c}_{\mathrm{EX} \mathrm{N}, \mathrm{ST}, \mathrm{i}}$ & 1.24 & 1.16 & CS I,ENV,i & 0.49 & -0.27 \\
\hline cEC IRR,RES,i & 0.36 & -0.04 & CENV LCA, i & 0.7 & -0.47 \\
\hline $\mathrm{C}_{\mathrm{EC}}$ TOC,i & 0.58 & -0.43 & $\mathrm{C}_{\mathrm{ENV}} \mathrm{E}, \mathrm{CO} 2, \mathrm{i}$ & 0.54 & -0.32 \\
\hline $\mathrm{c}_{\mathrm{EC}} \mathrm{LCC}, \mathbf{i}$ & 0.71 & -0.71 & $\mathrm{C}_{\text {ENV C,RES, }} \mathrm{i}$ & 0.37 & 0.23 \\
\hline $\mathrm{C}_{\mathrm{EC}} \mathrm{TC}, \mathrm{INV}, \mathrm{i}$ & 0.86 & -0.38 & CENV EPBT, i & 0.36 & -0.12 \\
\hline $\mathrm{C}_{\text {EC DGC, RES, } \mathrm{i}}$ & 0.39 & $-0,12$ & $\mathrm{C}_{\text {ENV GPBT, } \mathrm{i}}$ & 0.33 & -0.17 \\
\hline
\end{tabular}

The DEMATEL method was used to determine the value of relation weights for individual decision criteria and sub-criteria. The normalized weights of the relations between the main criteria and sub-criteria of evaluation are presented in Table 2. Relative weights with the value over $15 \%$ for the main criteria and over $3.5 \%$ for the sub-criteria of evaluation were marked in bold. 
Table 2. Normalized weights determining the importance and relations for individual main criteria and sub-criteria of evaluation.

\begin{tabular}{|c|c|c|c|}
\hline \multicolumn{3}{|c|}{$\mathbf{v}^{\text {Savg }_{i}}$} & \multirow{2}{*}{$\begin{array}{c}\mathrm{v}^{\text {Savg }_{i}} \\
0.072\end{array}$} \\
\hline $\mathbf{c}_{\mathbf{T}}$ & 0.17 & $\mathbf{c}_{\mathrm{T} \mathbf{A} / \mathrm{V}, \mathbf{i}}$ & \\
\hline $\mathrm{c}_{\mathrm{EN}}$ & 0.23 & $\mathrm{c}_{\mathrm{T} T, \mathrm{BLD}, \mathrm{i}}$ & 0.027 \\
\hline$c_{E X}$ & 0.17 & $\mathrm{c}_{\mathrm{T}} \mathrm{D}, \mathrm{IMP}, \mathrm{i}$ & 0.027 \\
\hline $\mathrm{c}_{\mathrm{EC}}$ & 0.21 & $\mathrm{c}_{\mathrm{T}} \mathrm{T,LIFE,i}$ & 0.024 \\
\hline $\mathrm{c}_{\mathrm{S}}$ & 0.1 & $\mathrm{c}_{\mathrm{T}} \mathrm{T}, \mathrm{RES}, \mathrm{i}$ & 0.02 \\
\hline \multirow[t]{5}{*}{ cENV } & 0.13 & CEN PE,TOTAL,i & 0.036 \\
\hline & & CEN UE,TOTAL,i & 0.047 \\
\hline & & $\mathrm{c}_{\text {EN FE,TOTAL,i }}$ & 0.043 \\
\hline & & $\mathrm{c}_{\mathrm{EN}} \mathrm{UE}, \mathrm{RES}, \mathrm{i}$ & 0.038 \\
\hline & & $\mathrm{C}_{\mathrm{EN}} \mathrm{FE}, \mathrm{RES}, \mathrm{i}$ & 0.033 \\
\hline $\mathrm{c}_{\mathrm{EX} B, \mathrm{~B}, \mathrm{i}}$ & 0.035 & CS TC,i & 0.022 \\
\hline cEX B,GEN,RES, i & 0.045 & CS AQ,i & 0.021 \\
\hline $\mathrm{c}_{\mathrm{EX} B, \mathbf{P}, \mathbf{i}^{*}}$ & 0.026 & $\mathrm{C}_{\mathrm{S}} \mathrm{AC}, \mathrm{i}$ & 0.019 \\
\hline CEX UTIL,RES, i & 0.045 & CS VC,i & 0.02 \\
\hline $\mathrm{c}_{\mathrm{EX} \mathrm{N}, \mathrm{ST}, \mathrm{i}}$ & 0.085 & CS I,ENV,i & 0.027 \\
\hline $\mathrm{c}_{\mathrm{EC}}$ IRR,RES,i & 0.027 & c ENV LCA, i & 0.031 \\
\hline $\mathrm{c}_{\mathrm{EC} \text { TOC,i }}$ & 0.028 & $\mathrm{C}_{\mathrm{ENV}} \mathrm{E}, \mathrm{CO} 2, \mathrm{i}$ & 0.028 \\
\hline $\mathrm{c}_{\mathrm{EC}} \mathrm{LCC}, \mathrm{i}$ & 0.027 & $\mathrm{C}_{\text {ENV C,RES, i }}$ & 0.033 \\
\hline $\mathrm{c}_{\mathrm{EC}} \mathrm{TC}, \mathrm{INV}, \mathrm{i}$ & 0.039 & $\mathrm{C}_{\text {ENV EPBT, } \mathrm{i}}$ & 0.025 \\
\hline $\mathrm{c}_{\mathrm{EC}}$ DGC, RES, i & 0.027 & C ENV GPBT, i & 0.023 \\
\hline
\end{tabular}

After performing the analysis with the DEMATEL method, it is possible to accurately characterize the relations, or the lack of them, between the individual main criteria and subcriteria of evaluation for the design process of residential buildings with a positive energy balance. All relations between various criteria and sub-criteria of evaluation should be taken into account. The advantage of the method used is that it is transparent in reflecting the interrelations between a wide set of elements. The analyst, on the basis of the feedback from the experts, can make comments about the effects (direction and significance) between the factors.

The most important evaluation criteria/sub-criteria are those that have a strong causal character and influence other evaluation criteria/sub-criteria the most. It means that the criteria illustrate the first priority factors to focus on when designing positive-energy residential buildings, and within them, further improvement potential must be sought.

On the basis of the analysis performed, the analyst may remove from the set of criteria/sub-criteria that show a strong effect character, which means that they are also influenced by other criteria/sub-criteria. The same criteria/sub-criteria can also remain in the set of evaluation criteria/sub-criteria, providing added value for the decisionmaker (wider set of decision criteria). Thus, the decisionmaker is aware that all factors (characteristics) influencing the design process of positive-energy residential buildings were considered.

The tool, i.e., the DEMATEL method, fulfills the expected function and enables the identification of the relations between the criteria and sub-criteria of evaluation. The results obtained using the research method serve as weights of relations, which are used in the methodology for designing residential buildings with a positive energy balance.

\subsection{Social Research Method Survey Defining the Decisionmaker's Preferences}

A social research method, a target group survey, is aimed at aggregating partial valuations (i.e., determining the direct weights of the decision criteria and sub-criteria, and the preferences of the decisionmaker) for the possible variants of solutions for residential buildings with a positive energy balance, this way a model of the decisionmaker's preferences is created. For this purpose, an original questionnaire was proposed, which was distributed to the decisionmakers clearly interested in the construction of the buildings in question, and to people who currently live in such houses. The group of respondents for the study 
may include designers, contractors, investors (developers), students of environmental engineering, current and future users.

In order to create a model of the decisionmaker's preferences, it was necessary to obtain information on the preferences of individual decisionmakers regarding the selection of a residential building with a positive energy balance. More specifically, to obtain weights for individual decision criteria. To that end, it was necessary to create a questionnaire surveying the decisionmaker's preferences, select a target group (individuals clearly interested in the construction of residential buildings with a positive energy balance, i.e., designers, contractors, investors (developers), students, current and future users, architects, energy auditors and others) and people who currently live in such houses, and finally, conduct the survey and statistical analysis.

The decisionmakers compared the main criteria and sub-criteria of evaluation within a given main criterion. For pairwise comparison of elements, a discrete and non-negative evaluation was used in accordance with the analytic hierarchy process and the analytic network process (AHP/ANP); specifically, the nine-point scale by Saaty which symbolizes the degree of advantage (scale of dominance/preference) of one of the evaluation criteria, considered within a pair, over the other, where point 1 corresponds to no advantage. Both criteria are equally important.

The respondent, using the degree of advantage (scale of domination/preference), used to evaluate pairwise comparisons and interpreted in the manner presented in the questionnaire, was asked to assign for each pair the value of the relation (determining the advantage of importance), from absolutely more important $(-9 /+9)$ to equally important (1). The pairwise comparisons aimed to select the decision criteria of the highest significance according to a given respondent, which contributes to the achievement of the goal, i.e., selecting the most favorable solution for buildings with a positive energy balance. All questions regarding the determination of the intensity of importance were closed-ended, in each of them the respondent marked a numerical value on the Saaty's scale axis. In the case of the expert questionnaire, pairwise comparison was used in the questionnaire surveying the decisionmaker's preferences, which is the easiest way for the respondents to provide the correct answer, it is intuitive. The decision sub-criterion on the left side of the scale was always compared to all the other decision sub-criteria on the right side. The pairs were grouped according to the order of decision criteria and sub-criteria in a tabular manner. The questionnaire is legible and transparent, and the use of this type of solution facilitates the working process, and a situation in which the respondents were unable to provide answers was excluded. The advantage of the adopted survey structure, similarly to the expert survey, is that the statistical analysis of the data can be easily conducted.

An important element of the social research carried out using a survey is the correct selection of the sample and quality of respondents, i.e., people who fill in the questionnaire scrupulously, devoting due attention and time to it, and who have appropriate knowledge and expertise in the analyzed subject. The prepared questionnaire of the decisionmaker's preferences should be addressed to individuals who show clear interest in the construction of residential buildings with a positive energy balance, and to those who currently live in such houses. The group of respondents for the study may comprise of designers, contractors, investors (developer), students of architecture, construction or environmental engineering, current and future users, architects, energy auditors and others. The selection of the group of respondents depending on the category must be strictly defined.

The prepared questionnaire of the decisionmaker's preferences was addressed to individuals who show clear interest in the construction of residential buildings with a positive energy balance (according to the answers to question no. 11,79.2\% were interested in the construction of such a building, while only $15.1 \%$ of decisionmakers were not), and those who currently live in that type of buildings (according to the answers to question no. $11-5.7 \%)$. The group of respondents for the study comprised of designers, contractors, investors (developers), students of environmental engineering, current and future users, 
architects, energy auditors and others. The selection of the group of respondents depending on the category was strictly defined (BUDMA 2019/PIBP) or random (WOIIB/RI).

The distribution of the decisionmakers' preference questionnaires was divided into four categories:

1. Paper-based questionnaires, distributed during BUDMA 2019 trade fair during the author's presentation on the installation of technical equipment for buildings in passive houses, 60 copies;

2. Source_a, distribution by the Greater Poland District Chamber of Civil Engineers (WOIIB), no limit;

3. Wersja_1, distribution by Rynek Instalacyjny (RI) periodical, no limit;

4. Ver_1, distribution by a database of certified designers of the Polish Passive House Institute (PIBP) and people from the passive construction community, 15 copies.

Completed decisionmakers' preference questionnaires were received from 30 people during BUDMA 2019, from 5 people through WOIIB, from 8 people through RI periodical and from 10 people related to passive housing. A total of 53 questionnaires were completed, which is a satisfactory sample.

It was decided that a statistical analysis of the data divided into specific groups of respondents would be conducted, and for a given group, Table S4 shows the distribution of the frequency of the evaluation marks provided by individual decisionmakers. The following groups were distinguished:

- Designer/Architect;

- Contractor;

- Current user;

- Future user;

- Investor (developer).

In Table S4, the last column shows calculations of the geometric consistency index (GCI). The collected evaluations made by the surveyed target group show high reliability and accuracy of the respondents' evaluations. There are no grounds to revise the value of the evaluations made by all $\mathrm{K}$ respondents. Only in the group current user, for comparisons under question no. 7, the condition of consistency of evaluations was not met. Therefore, a decision was made to merge the group current user with the group future user. After merging both groups, the condition of consistency of evaluations was met. The calculations after combining the two groups are shown in Table S4.

In order to determine the weight vectors of the selected evaluation criteria, the AHP / ANP analysis was performed using the geometric mean. The calculations were made taking into account all surveyed respondents (decisionmakers). In turn, the matrices of comparisons of the main criterion and sub-criteria was created with the determination of the order of decision variants. Table S5 presents the matrices of comparisons of the main criterion and sub-criteria with the determination of the order of decision variants.

Table 3 and Figure 2 show the normalized preference evaluations for the main criteria, while Table 4 presents the normalized values for the sub-criteria of evaluation within a given main criterion, as well as raw data from the limit supermatrix and the same values normalized as part of a whole.

After determining the weight vectors of the selected evaluation criteria, they can be classified from the most preferred (those having a high value) to the least important (those having a low value). On the basis of the conducted analysis, the analyst may remove from the set of criteria/sub-criteria those that have the lowest value, which means that they are the least preferred by the decisionmaker. The same criteria/sub-criteria, similarly to the expert survey stage, may remain in the set of evaluation criteria/sub-criteria, constituting an added value for the decisionmaker (a wider set of decision criteria). This way, the decisionmaker is aware that all factors (characteristics) influencing the process of designing residential buildings with a positive energy balance were considered. 
As a tool, the AHP / ANP method fulfills the expected function and enables the ranking of evaluation criteria and sub-criteria. The results obtained with the research method serve as weights of the decisionmakers' preferences, which are used in the methodology for designing residential buildings with a positive energy balance.

In order to confirm the applicability of the proposed methodology for designing residential buildings with a positive energy balance, it is necessary to provide computational examples.

Table 3. Weight vectors for the main evaluation criteria, all decisionmakers.

\begin{tabular}{|c|c|c|c|}
\hline \multirow[t]{2}{*}{ Criterion Group } & \multirow{2}{*}{ Name of Evaluation Criterion } & \multirow{2}{*}{$\begin{array}{c}\text { Normalized Value } \\
\text { Within a Group }\end{array}$} & \multirow{2}{*}{$\begin{array}{c}\text { Raw } \\
\text { Value }\end{array}$} \\
\hline & & & \\
\hline$(-)$ & $(-)$ & $(-)$ & $(-)$ \\
\hline \multirow{6}{*}{ Criterion } & Technical criterion & 0.14159 & 0.070797 \\
\hline & Energy criterion & 0.23588 & 0.117942 \\
\hline & Exergy criterion & 0.18417 & 0.092085 \\
\hline & Economic criterion & 0.25527 & 0.127637 \\
\hline & Social criterion & 0.07976 & 0.03988 \\
\hline & Environmental criterion & 0.10332 & 0.051659 \\
\hline
\end{tabular}

\section{Main criteria}

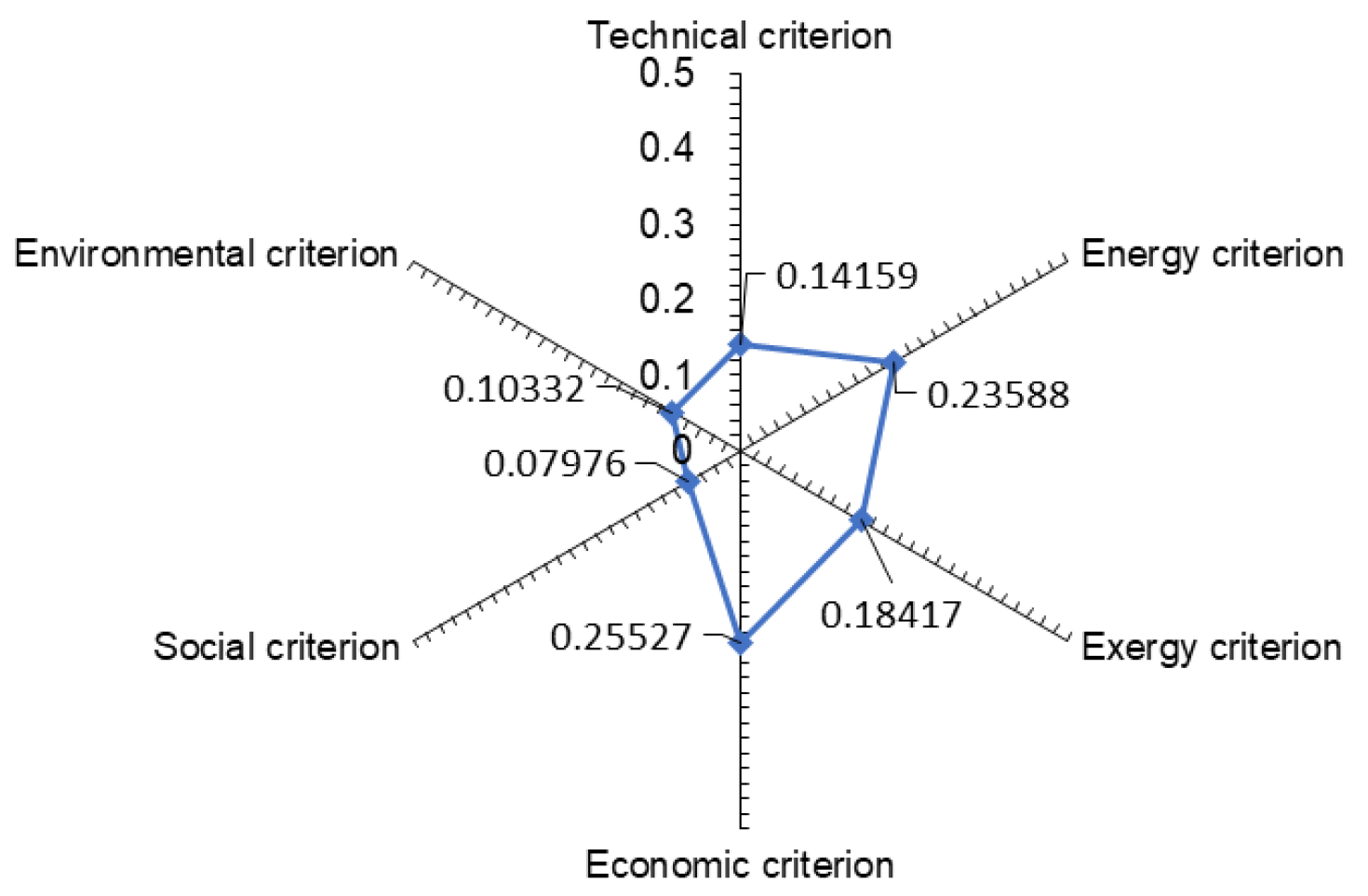

Figure 2. Comparison of the evaluations of all decisionmakers' preferences. 
Table 4. Weight vectors for all sub-criteria of evaluation, all decisionmakers.

\begin{tabular}{|c|c|c|c|c|}
\hline Criterion Group & Name of Evaluation Sub-Criteria & Normalized Within a Group & Raw Value & Normalized As Part of a Whole \\
\hline$[-]$ & {$[-]$} & {$[-]$} & {$[-]$} & {$[-]$} \\
\hline \multirow{4}{*}{ Technical criterion } & Shape factor $(\mathrm{A} / \mathrm{V})$ & 0.1835 & 0.012991 & 0.025982 \\
\hline & Total building completion time (TBLD) & 0.12383 & 0.008767 & 0.017534 \\
\hline & Total service life of the building and its technical installations (TLIFE) & 0.29753 & 0.021064 & 0.042128 \\
\hline & Total service life of renewable energy installation (TRES) & 0.26534 & 0.018785 & 0.03757 \\
\hline \multirow{4}{*}{ Energy criterion } & Total primary energy consumption (PETOTAL) & 0.12019 & 0.014176 & 0.028352 \\
\hline & Total usable energy consumption (UETOTAL) & 0.29045 & 0.034256 & 0.068512 \\
\hline & Total final energy consumption (FETOTAL) & 0.14817 & 0.017475 & 0.03495 \\
\hline & Total transmitted final renewable energy (FERES) & 0.19983 & 0.023568 & 0.047136 \\
\hline \multirow{5}{*}{ Exergy criterion } & Sum of exergy losses of the building and its installations (BL) & 0.2147 & 0.019771 & 0.039542 \\
\hline & Sum of exergy generated by renewable energy sources (BGEN,RES) & 0.15147 & 0.013948 & 0.027896 \\
\hline & Cumulated primary exergy consumption $\left(\mathrm{BP}^{*}\right)$ & 0.09422 & 0.008676 & 0.017352 \\
\hline & Utilization of the generated renewable energy (UTILRES) & 0.23019 & 0.021197 & 0.042394 \\
\hline & Use of natural heating, cooling and lighting strategies (NST) & 0.30942 & 0.028493 & 0.056986 \\
\hline \multirow{4}{*}{ Economic criterion } & Internal return rate on renewable energy sources (IRRRES) & 0.13842 & 0.017667 & 0.035334 \\
\hline & Total operational cost (TOC) & 0.16395 & 0.020926 & 0.041852 \\
\hline & Analysis of the building's life-cycle cost (LCC) & 0.2721 & 0.03473 & 0.06946 \\
\hline & Total prime cost of the investment (TCINV) & 0.30949 & 0.039502 & 0.079004 \\
\hline \multirow{4}{*}{ Social criterion } & Compliance with the air quality parameters (AQ) & 0.33185 & 0.013234 & 0.026468 \\
\hline & Compliance with the acoustic comfort parameters (AC) & 0.15547 & 0.0062 & 0.0124 \\
\hline & Compliance with the visual comfort parameters (VC) & 0.11349 & 0.004526 & 0.009052 \\
\hline & Impact of the building and its installations on the surrounding environment (IENV) & 0.11723 & 0.004675 & 0.00935 \\
\hline \multirow{5}{*}{ Environmental criterion } & Lice-cycle analysis of the building (LCA) & 0.2497 & 0.012899 & 0.025798 \\
\hline & Carbon dioxide emission (ECO2) & 0.21675 & 0.011197 & 0.022394 \\
\hline & Coherence of renewable energy sources (CRES) & 0.17314 & 0.008944 & 0.017888 \\
\hline & Energy payback time of renewable energy sources (EPBT) & 0.20004 & 0.010334 & 0.020668 \\
\hline & Greenhouse gas emission payback time (GPBT) & 0.16038 & 0.008285 & 0.01657 \\
\hline
\end{tabular}




\section{Discussion}

The study discusses a proposal of an innovative approach to designing buildings, which can be applied at the stage of a construction concept, a methodology developed for designing buildings with a positive energy balance. It is based on the proposed algorithm consisting of 5 stages. The first is the construction of an input database for a specific project, the second is the identification of permissible and acceptable solutions for a residential building with a positive energy balance. The third and crucial stage is the creation of a set of decision criteria and the selection of those that meet a number of postulates, characterized by exhaustive nature, consistency and non-redundancy. At that stage, it was necessary to identify the relations between the decision criteria, which were determined by surveying a group of experts using the Delphi method. The fourth stage consisted in determining the preferences of the decisionmaker. They were identified by surveying a target group (people clearly interested in the construction of the buildings in question) with the use of social research.

The algorithm ends the fifth stage, in which the values of the variables were calculated and normalized, and a ranking of permissible and acceptable variants of solutions was created which concluded with the choice of a compromise solution. The prepared algorithm indicates the need for changes in the classic design of residential buildings, taking into account the decision-making criteria that show interdependence. The proposed methodology consists in combining three methods of multi-criteria decision support: the DEMATEL method, used to determine the relations between decision criteria; the AHP/ANP method, used to build a model of the decisionmaker's preferences; and the TOPSIS method, used to create a ranking of permissible and acceptable variants of solutions.

The proposed methodology should be tested using several computational examples involving the selection of a compromise solution for single-family and multi-family residential buildings with a positive energy balance. As a result of the performed calculations, a final order of the analyzed variants is obtained, from the most preferred to the least accepted solution. The methodology used for the case studies carried out should demonstrate its applicability. The developed methodology facilitates the process of designing residential buildings with a positive energy balance, which is an extremely complex process.

\section{Conclusions}

Multi-criteria decision support methods were used to create a methodology for designing residential buildings with a positive energy balance. For this purpose, it was necessary to create a unified algorithm that takes into account the identification of a set of permissible solutions, evaluation criteria and sub-criteria, the determination of the relations between them, and the creation of a model of the decisionmaker's preferences. The effective use of the algorithm requires determining the weights of relations for individual decision criteria based on the Delphi study of a selected group of experts, and calculating the preference weights based on statistical studies of the decisionmakers. Taking into account the relations between the decision criteria influences the choice of a compromise solution, regardless of the creation of a model of the decisionmaker's preferences. The selected group of decision sub-criteria can be modified by introducing additional or changing the existing sub-criteria, which may affect the importance of a specific indicator included in the analysis.

The applicability of the presented methodology can be extended to include other types of objects. For this purpose, statistical surveys of the target group (decisionmakers) should be re-conducted. The methodology proposed in the work may in the future be extended by adjusting the algorithm to analyze the possibility of choosing a compromise solution for deep modernization of existing buildings to the building standard with a positive energy balance. In the investment-planning phase, the proposed methodology can be integrated with the building information modeling system (BIM) in order to obtain the full profile of the building in question, which may yield a better proposition of potentially possible variants of solutions and results precisely defining the impact of the action taken on the final result. 
Supplementary Materials: The following are available online at https: / www.mdpi.com/article/ 10.3390/en14154715/s1, Table S1: Set of selected decision criteria. Table S2: Distribution of the frequency of evaluation marks for the intensity of impact given by experts, the geometric mean, the median, the modal value, the column presenting the lack of impact, and the consistency index. Table S3: Expert questionnaire-matrices in accordance with the DEMATEL method. Table S4: Distribution of the frequency of evaluation marks given by individual decisionmakers, the geometric mean, the median, the modal value, and the consistency index. Table S5: Questionnaire of the decision-maker's preferences-Pairwise comparison matrices for all decision-makers.

Author Contributions: Conceptualization, B.R. and T.M.; methodology, B.R.; formal analysis, B.R.; investigation, B.R.; resources, B.R.; writing-original draft preparation, B.R.; writing-review and editing, T.M.; visualization, B.R.; supervision, T.M. All authors have read and agreed to the published version of the manuscript.

Funding: This publication was funded by the Polish Ministry of Science and Higher Education, research subsidy number SBAD/0938/2020.

Institutional Review Board Statement: Not applicable.

Informed Consent Statement: Not applicable.

Data Availability Statement: This work is based on the results of Bartosz Radomski Ph.D. thesis entitled "The methodology of designing residential buildings with a positive energy balance" (original title: "Metodyka projektowania budynków mieszkalnych o dodatnim bilansie energetycznym") under the supervision of Tomasz Mroz.). The data presented in this study are openly available in https: / / sin.put.poznan.pl/ files/download/35489, accessed on 25 June 2021.

Conflicts of Interest: The authors declare no conflict of interest.

\section{References}

1. Kabak, M.; Köse, E.; Kırılmaz, O.; Burmaoglu, S. A fuzzy multi-criteria decision-making approach to assess building energy performance. Energy Build. 2014, 72, 382-389. [CrossRef]

2. Hepbasli, A. Low exergy (LowEx) heating and cooling systems for sustainable buildings and societies. Renew. Sustain. Energy Rev. 2012, 16, 73-104. [CrossRef]

3. Slonski, M.; Schrag, T. Linear Optimisation of a Settlement Towards the Energy-Plus House Standard. Energies 2019, 12, 210. [CrossRef]

4. Ciancio, V.; Falasca, S.; Golasi, I.; de Wilde, P.; Coppi, M.; de Santoli, L.; Salata, F. Resilience of a Building to Future Climate Conditions in Three European Cities. Energies 2019, 12, 4506. [CrossRef]

5. Rucińska, J.; Trząski, A. Measurements and Simulation Study of Daylight Availability and Its Impact on the Heating, Cooling and Lighting Energy Demand in an Educational Building. Energies 2020, 13, 2555. [CrossRef]

6. Berouine, A.; Ouladsine, R.; Bakhouya, M.; Essaaidi, M. Towards a Real-Time Predictive Management Approach of Indoor Air Quality in Energy-Efficient Buildings. Energies 2020, 13, 3246. [CrossRef]

7. Grygierek, K.; Ferdyn-Grygierek, J.; Gumińska, A.; Baran, Ł.; Barwa, M.; Czerw, K.; Gowik, P.; Makselan, K.; Potyka, K.; Psikuta, A. Energy and Environmental Analysis of Single-Family Houses Located in Poland. Energies 2020, 13, 2740. [CrossRef]

8. Directive 2010/31/EU of the European Parliament and of the Council of 19 May 2010 on the Energy Performance of Buildings. Available online: http:/ / www.passiv.de/ (accessed on 7 March 2021).

9. Passive House Institute (PHI). Passive House Planning Package, Energy Balance and Passive House Design Tool for Quality Approved Passive Houses and EnerPHit Retrofits, Version 9; Passive House Institute (PHI): Darmstadt, Germany, 2015.

10. Passive House Institute (PHI). Criteria for the Passive House, EnerPHit and PHI Low Energy Building Standard, Version 9f; Passive House Institute (PHI): Darmstadt, Germany, 2016.

11. Radomski, B. Projektowanie instalacji sanitarnych w budynkach pasywnych-Studium przypadku. Inżynier Budownictwa 2016, 9, 84-89.

12. Radomski, B. Projektowanie w budynkach pasywnych instalacji ziębniczej, przygotowania ciepłej wody użytkowej i wentylacji mechanicznej nawiewno-wywiewnej. Inżynier Budownictwa 2016, 11, 113-117.

13. Radomski, B.; Bandurski, K.; Mróz, T.M. Rola parametrów komfortu klimatycznego w budynkach pasywnych. Instal 2017, 10, 27-33.

14. Firlag, S. Cost-Optimal Plus Energy Building in a Cold Climate. Energies 2019, 12, 3841. [CrossRef]

15. Erhorn, H. The Age of Positive Energy Buildings Has Come; Fraunhofer Institute for Building Physics: Stuttgart, Germany, 2012; pp. 1433-1443.

16. Kampelis, N.; Sifakis, N.; Kolokotsa, D.; Gobakis, K.; Kalaitzakis, K.; Isidori, D.; Cristalli, C. HVAC Optimization Genetic Algorithm for Industrial Near-Zero-Energy Building Demand Response. Energies 2019, 12, 2177. [CrossRef] 
17. Mróz, T.M.; Radomski, B. Aspekty energetyczne współczesnego środowiska zabudowanego. Przegląd Bud. 2018, 7, 102-104.

18. Shi, X.; Tian, Z.; Chen, W.; Si, B.; Jin, X. A review on building energy efficient design optimization from the perspective of architects. Renew. Sustain. Energy Rev. 2016, 65, 872-884. [CrossRef]

19. Schmidt, D. Low exergy systems for high-performance buildings and communities. Energy Build. 2009, 3, 331-336. [CrossRef]

20. Sakulpipatsin, P. Exergy Efficient Building Design. Ph.D. Thesis, Delft University of Technology, Delft, The Netherlands, 2008.

21. Sakulpipatsin, P.; Boelman, E.; Schmidt, D. Exergy Analysis Tool for Building Service Design. In Proceedings of the Sustainable Building Conference, Tokyo, Japan, 27-29 September 2005.

22. Wright, J.; Loosemore, H. The multi-criterion optimization of building thermal design and control. Building Simulation. In Proceedings of the Seventh International IBPSA Conference, Rio de Janeiro, Brazil, 13-15 August 2001; pp. 873-880.

23. Caldas, L.; Norford, L.K. Genetic Algorithms for Optimization of Building Envelopes and the Design and Control of HVAC Systems. J. Sol. Energy Eng. 2003, 125, 343-351. [CrossRef]

24. Dytczak, M. Wybrane Metody Rozwiazywania Wielokryterialnego Problemów Decyzyjnych w Budownictwie; Politechnika Opolska: Opole, Poland, 2010.

25. Saaty, T.L. A scaling method for priorities in hierarchical structures. J. Math. Psychol. 1977, 15, 234-281. [CrossRef]

26. Pacheco, R.; Ordóňez, J.; Martínez, G. Energy efficient design of building: A review. Renew. Sustain. Energy Rev. 2012, 16, 3559-3573. [CrossRef]

27. Kurnitski, J.; Saari, A.; Kalamees, T.; Vuolle, M.; Niemelä, J.; Tark, T. Cost optimal and nearly zero (nZEB) energy performance calculations for residential buildings with REHVA definition for nZEB national implementation. Energy Build. 2013, 64, 258-263. [CrossRef]

28. Rodriguez-Ubinas, E.; Rodriguez, S.; Voss, K.; Todorovic, M.S. Energy efficiency evaluation of zero energy houses. Energy Build. 2014, 83, 23-35. [CrossRef]

29. Ballarini, I.; Corrado, V. Application of energy rating methods to the existing building stock: Analysis of some residential buildings in Turin. Energy Build. 2009, 41, 790-800. [CrossRef]

30. Holopainen, R.; Salmi, K.; Kähkönen, E.; Pasanen, P.; Reijula, K. Primary energy performance and perceived indoor environment quality in Finnish low-energy and conventional houses. Build. Environ. 2015, 87, 87-92. [CrossRef]

31. Frontczak, M.; Schiavon, S.; Goins, J.; Arens, E.; Zhang, H.; Wargocki, P. Quantitative relationships between occupant satisfaction and satisfaction aspects of indoor environmental quality and building design. Indoor Air 2012, 22, 119-131. [CrossRef]

32. Saaty, T.L. The Analytic Network Process, Fundamentals of Decision Making and Priority Theory; RWS Publications: Pittsburgh, PA, USA, 2001.

33. Saaty, T.L. Decision making the Analytic Hierarchy and Network Processes (AHP/ANP). J. Syst. Sci. Syst. Eng. 2004, 13, 1-35. [CrossRef]

34. Saaty, T.L. Decision Making with Dependence and Feedback: The Analytic Network Process; RWS Publications: Pittsburgh, PA, USA, 1996.

35. Saaty, T.L. The Analytic Hierarchy Process: Planning, Priority Setting; RWS Publications: Pittsburgh, PA, USA, 1980.

36. Saaty, T.L. Fundamentals of the Analytic Network Process. In Proceedings of the ISAHP 1999, Kobe, Japan, 12-14 August 1999.

37. Ou Yang, Y.-P.; Shieh, H.-M.; Leu, J.-D.; Tzeng, G.-H. A Novel Hybrid MCDM Model Combined with DEMATEL and ANP with Applications. Int. J. Oper. Res. 2008, 5, 160-168.

38. Gölcük, I.; Baykasoğu, A. An analysis of DEMATEL approaches for criteria interaction handling within ANP. Expert Syst. Appl. 2016, 46, 346-366. [CrossRef]

39. Chen, F.-H.; Hsu, T.-S.; Tzeng, G.-H. A balanced scorecard approach to establish a performance evaluation and relationship model for hot spring hotels based on a hybrid MCDM model combining DEMATEL and ANP. Int. J. Hosp. Manag. 2011, 30, 908-932. [CrossRef]

40. Radomski, B.; Mróz, T.M.; Grządzielski, W. Wybór sposobu zasilania w energię pierwotną wyspowych układów energetycznych z wykorzystaniem LNG-Studium przypadku. Cieptownictwo Ogrzew. Went. 2016, 47, 47-54. [CrossRef]

41. Tsai, W.-H.; Leu, J.-D.; Liu, J.-Y.; Lin, S.-J.; Shaw, M.J. A MCDM approach for sourcing strategy mix decision in IT projects. Expert Syst. Appl. 2010, 37, 3870-3886. [CrossRef] 